\section{Karl Gustaf Torsten Sjögren and Sjögren-Larsson syndrome}

\author{
Khalid Al Aboud, ${ }^{1}$ Daifullah Al Aboud \\ 'Dermatology Department, King Faisal \\ Hospital, Makkah; \\ 2Dermatology Department, Taif \\ University, Taif, Saudi Arabia
}

Karl Gustaf Torsten Sjögren (1896-1974), (Figure 1), a Swedish psychiatrist and geneticist, was a pioneer of modern Swedish psychiatry. ${ }^{1-4}$ Sjögren studied medicine at the University of Uppsala. ${ }^{1}$ From 1932 to 1935 , he was Head Physician and Director of Lillehagen Hospital in Gothenburg, and between 19351945 , he was physician-in-chief at the psychiatric department of Sahlgrenska Hospital in Gothenburg. Sjögren was professor of psychiatry at Karolinska Institutet from 1945 to 1961 and was elected to the Royal Swedish Academy of Sciences in $1951 .^{3}$

Sjögren was an expert of psychiatry for the World Health Organization. ${ }^{3}$ Among his many contributions to medicine, he is credited for describing several medical conditions, ${ }^{5-8}$ which were later named after him, including GraefeSjögren syndrome, Marinesco-Sjögren syndrome, and Sjögren-Larsson syndrome (SLS).

During his work on juvenile amaurotic idiocy, Sjögren forged a collaboration with Tage K.L. Larsson, a statistics lecturer at the University of Lund. ${ }^{3}$ Their study on the combination of oligophrenia, congenital ichthyosis, and spastic disorders in 1957 established the clinical and genetic profile of a new disease entity, later known as Sjogren-Larsson syndrome (SLS). ${ }^{3}$

\section{Sjögren-Larsson syndrome}

Sjögren-Larsson syndrome - also known in OMIM as ichthyosis, spastic neurologic disorder, and oligophrenia - is a rare autosomal recessive condition comprising congenital ichthyotic hyperkeratosis, spastic diplegia, mild to moderate mental retardation, and retinopathy. ${ }^{9-12}$ Hair, nails, and the ability to sweat are generally normal. SLS was originally described in Swedish patients, but over 200 cases have been reported worldwide in all races. The incidence in Sweden is 1 in 100,000 , rising to 1 in 10,000 in the northwest region of Vasterbotten. ${ }^{10}$

SLS presents at birth as ichthyosis that ranges from fine scaling to generalized hyperkeratosis. Preterm birth is common and is been attributed to abnormal leukotriene B4 inactivation..$^{10}$ Velvety orange or brown lichenification, often with verrucous hyperkeratosis, develops noticeably in and around the flexures, neck, and midabdomen. The lichenification progresses slowly and is embarrassing to older

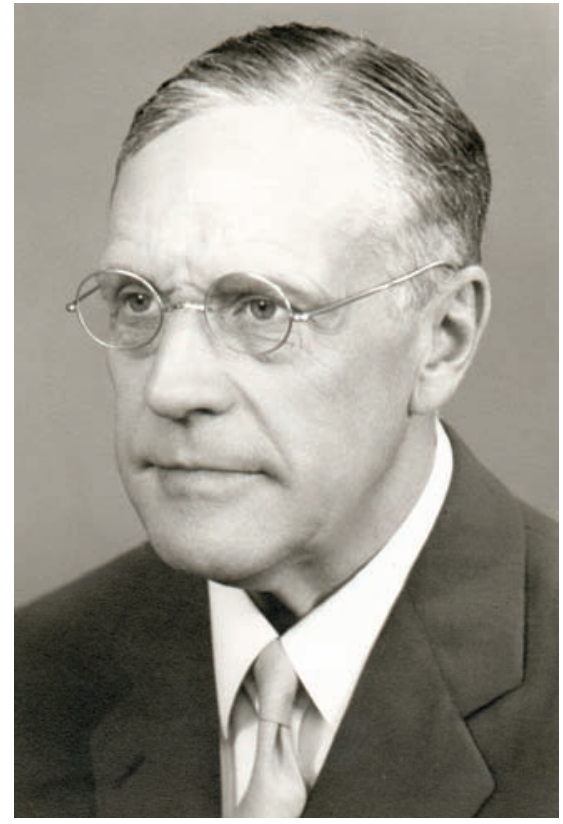

Correspondence: Khalid Al Aboud, MD, P.O Box 5440, Makkah 21955, Saudi Arabia.

E-mail:amoa65@hotmail.com

Key words: dermatology, skin, Sjögren-Larsson syndrome.

Received for publication: 20 August 2011.

Accepted for publication: 6 September 2011

This work is licensed under a Creative Commons Attribution NonCommercial 3.0 License (CC BYNC 3.0).

(C) Copyright K. Al Aboud and D. Al Aboud., 2011

Licensee PAGEPress, Italy

Dermatology Reports 2011; 3:e34

doi:10.4081/dr.2011.e34

4. Amark C. Torsten Sjogren and Swedish psychiatry: 1940-1960. Acta Psychiatr Scand 1963;39:11-8.

Figure 1. Karl Gustaf Torsten Sjögren (1896-1974). Image is provided by the Center for History of Science, the Royal Swedish Academy of Sciences. Permission for republication is granted by Norstedts, Sweden.

children, in whom it can restrict the mobility of already hypertonic limbs. ${ }^{10}$

In the first 2 to 3 years, SLS patients can develop neurological manifestations, such as spastic diplegia or tetraplegia and mental retardation, and can be accompanied by defects in speech. Glistening white dots develop in the macula of the retina after 1 year of age but are not present in all patients. Most SLS patients never walk ${ }^{9}$ and tend to have short stature. About half of SLS patients experience seizures. The histological findings of hyperkeratosis, papillomatosis, acanthosis, and a mildly thickened granular layer are nonspecific. ${ }^{11}$

SLS is caused by a deficiency in fatty aldehyde dehydrogenase (FALDH), which maps to 17p11.2. Mutations occur in the FALDH gene (ALDH10, recently renamed ALDH3A2). ${ }^{11}$ Clinical improvements occurs with fat restriction and supplementation with medium-chain triglycerides. ${ }^{9}$

\section{References}

1. Ole Daniel Enersen. Who named it? Karl Gustaf Torsten Sjögren. http://www. whonamedit.com/doctor.cfm/1609.html Accessed: 5 April 2011.

2. Wikipedia, the free encyclopedia. Torsten Sjögren.http://en.wikipedia.org/wiki/Torste n_Sj\%C3\%B6gren Accessed: 15 April 2011.

3. Alstrom CH, Stromgren E. Torsten Sjogren. Acta Psychiatr Scand 1963;39:5-10.
5. Sjögren T. Hereditary congenital spinocerebellar ataxia accompanied by congenital cataract and oligophrenia. A genetic and clinical investigation. Confin Neurol 1950;10:293-308.

6. Sjögren T. Klinische und vererbungsmedizinische Untersuchungen über Oligophrenie mit kongenitaler Katarakt. Z Gesamte Neurol Psychiatr 1935;152:263-92.

7. Sjögren T. Hereditary congenital spinocerebellar ataxia combined with congenital cataract and oligophrenia. Acta Psychiatr Neurol Scand 1947;46(Suppl): 286-9.

8. Sjögren KGT, Larsson TK. Oligophrenie in combination with congenital ichtyosis and spastic disorders; a clinical and genetic study. Acta Psychiatr Neurol Scand Suppl 1957;113:1-112.

9. Johns Hopkins University. OMIM, Online Mendelian Inheritance in Man. SjogrenLarsson syndrome; SLS.http://omim.org/entry/270200Accessed: 5 April 2011.

10. Judge MR, McLean WH, Munro S. Disorders of Keratinization. In: Burn T, Breathnach S, Cox N, Griffiths C, eds. Rook's textbook of dermatology (8th edition). Oxford; Wiley-Blackwell; 2010. pp. 19-90.

11. Fleckman P, DiGiovanna JD. The ichthyoses. In: Wolff K, Goldsmith LA, Katz SI, Gilchrest B, Paller AS, Leffell DJ, eds. Fitzpatrick's Dermatology in General Medicine. 7th ed. New York, NY: McGraw Hill; 2008. pp. 401-424.

12. Cockerell CJ, Larsen F. Benign epidermal tumors and proliferations. In: Bolognia JL, Jorizzo JL, Rapini RP, Horn TD, Mascaro JM, Mancini AJ, et al., eds. Dermatology. Edinberg: Mosby; 2008. pp. 1668-1671. 